\title{
A REVIEW OF THE ROLE OF AGRICULTURAL EXTENSION AND TRAINING IN ACHIEVING SUSTAINABLE FOOD SECURITY: A CASE OF SOUTH AFRICA
}

\author{
Raidimi, E. N. ${ }^{1}$ and Kabiti, H. M. ${ }^{2}$ \\ Correspondence author: H. M. Kabiti. Email: kabitihlekani@ yahoo.co.uk
}

\begin{abstract}
The aim of this paper was to investigate the role of agricultural extension and training for sustainable food security. Improvement of a country's human capacity for productivity is a prerequisite for social and economic development. This study is a review of the envisaged role of agricultural extension and training for sustainable food security amongst smallholder farmers in South Africa. Findings revealed that agricultural extension can contribute to sustainable food security through knowledge dissemination to farmers, for informed decision making. However, for the extension personnel to be better equipped for knowledge dissemination and to realise the goal of sustainable food security, sustained agricultural extension human resource development through investment in education is a prerequisite. Moreover, institutions of higher education need to play a developmental role through establishing linkages with research, extension and farming communities in order to promote sustainable food security, and to increase the relevance of information and technology passed down to farmers. As such, there is a need for extension educators to ensure that training is responsive to the current needs of farmers. There is a need for models of extension education which are flexible enough to adapt to the environmental, social, economic and physical changes. Therefore, the findings of this study provide guidelines for reforms in extension education systems. This is of importance for informed policy crafting towards improved public extension services.
\end{abstract}

Keywords: Agricultural education, Agricultural production, Climate variability, Public extension, Smallholder farmer

\section{INTRODUCTION}

Since time immemorial, agriculture has been and continues to be the mainstay of rural economies in sub-Saharan Africa and throughout the developing world. In sub-Saharan Africa, 60 to $80 \%$ of the population is employed in agriculture, producing 15 to $50 \%$ of the Gross Domestic Product (GDP) (Organisation for Economic Co-operation Development (OECD), 2016; Staaz \& Dembele, 2008). Similarly, in South Asia, agriculture contributes between 22 and $28 \%$ of the GDP and employs around $60 \%$ of the labour force (International Labour Organisation (ILO), 2007). In South East Africa, East Asia and the Pacific, the percentage of the population employed in agriculture is between 40 and 50\%, with Latin America and the Caribbean with estimates of around $20 \%$ employment in the sector (ILO, 2007).

Agriculture in South Africa is one of the priority sectors, and is considered a key engine for economic growth, sustainable development and self-sufficiency (Department of Agriculture

\footnotetext{
${ }^{1}$ Senior Lecturer Agricultural Extension, Department of Agricultural Economics and Agribusiness, School of Agriculture, University of Venda, Thohoyandou, South Africa, Email: Nelson.Raidimi@ univen.ac.za, ORCiD: 0000-0001-8630-3851

${ }^{2}$ Researcher, Risk and Vulnerability Science Centre, Walter Sisulu University, Mthatha, South Africa, Email: kabitihlekani@yahoo.co.uk, ORCiD:0000-0003-1919-5824
} 
(DoA), 2005). Its aim is to increase food security and reduce poverty by supporting the effort of smallholder farmers at household level in rural areas where the economy is largely agrobased. Smallholder farmers are important drivers of the agriculture sector in these areas as they grow most of the food. These farmers, who are endowed with limited resources, have become the mainstay of food supply for millions of people in South Africa, and this situation is likely to progress for several years. The long-term goals of the agricultural sector in South Africa are to improve food security and reduce poverty by supporting the efforts of smallholders to increase agricultural productivity (Department of Agriculture, Forestry and Fisheries (DAFF), 2011). Despite all the government's efforts and well-intended policies, there is ample evidence that there has been very little progression and productivity of subsistence farmers in South Africa.

South Africa, according to Van Der Berg (2006), produces enough food to feed its population, but food insecurity is still a great concern for many households. According to Abdu-Raheem and Worth (2011), this situation is connected to elevated levels of poverty that exists in the country, particularly in rural areas. Food security is a situation that exists when all people, at all times, have physical, social and economic access to sufficient, safe and nutritious food that meets their dietary needs and food preferences for an active and healthy life (Abdu-Raheem \& Worth, 2011; Food and Agriculture Organisation of the United Nations (FAO), 2017). Establishing household food security is widely acknowledged as an important milestone in advancing the living standard of the rural poor. According to Abdu-Raheem and Worth (2011), one avenue towards realising this is through smallholder agriculture, which can be fostered through appropriate agricultural extension, education and training.

The DAFF employed 3369 extension officers to realise food security amongst smallholder farming communities in 2012 (Table 1). The number of extension officers available per province does not meet the farmers' requirements. Public extension services provide the baseline agricultural support needed by farmers. This is particularly important for smallholder farmers who have resource limitation in accessing private extension services (Raidimi \& Kabiti, 2017).

Table 1: Breakdown of extension officers employed in South Africa per province

\begin{tabular}{|l|l|l|}
\hline Province & Number & Percentage (\%) \\
\hline Eastern Cape & 867 & 25.7 \\
\hline Free State & 124 & 3.7 \\
\hline Gauteng & 91 & 2.7 \\
\hline KwaZulu Natal & 830 & 24.6 \\
\hline Limpopo & 818 & 24.3 \\
\hline Mpumalanga & 228 & 6.8 \\
\hline Northern Cape & 55 & 1.6 \\
\hline North West & 181 & 5.4 \\
\hline Western Cape & 175 & 5.2 \\
\hline TOTAL & $\mathbf{3 3 6 9}$ & $\mathbf{1 0 0}$ \\
\hline
\end{tabular}

Source: DAFF (2012)

The purpose of this paper was to outline the role of agricultural extension and training for sustainable food security, focusing on the potential role agricultural extension and training can play in addressing South African rural household food security concerns. 


\section{MATERIALS AND METHODS}

This paper is based on a literature review to relate the role of agricultural extension and education to sustainable food security amongst smallholder farmers in South Africa. Existing literature, policies, administrative records, and government reports provided information for this study. The first section focused on reviewing literature on the role of agricultural extension in South Africa, juxtaposing it with food security. Thereafter, a review on the preparedness of extension personnel to contribute to sustainable food security through agricultural education and training was articulated.

\section{RESULTS AND DISCUSSION}

\subsection{The role of agricultural extension in achieving sustainable food security}

One important way of supporting food security is through agricultural extension programmes. Agricultural extension is broadly defined as the process of development of agricultural knowledge and skills amongst farmers, aimed at increasing their productivity and realising other desirable changes (Collett \& Gale, 2009). Agricultural extension has multiple goals, including transferring knowledge from global, national, and local researchers to farmers, helping them clarify their own goals and assessing their opportunities, educating them about decision-making processes, and promoting desirable agricultural development (Msuya et al, 2017).

The knowledge transfer role of agricultural extension has gained traction in the face of increased climatic variability which culminates to weather unpredictability and rapidly changing environmental conditions (Zwane \& Montmasson-Clair, 2016). The changes linked to climate change impact the annual average temperature and rainfall, as well as the distribution thereof (Campbell et al, 2014). Furthermore, climate change has resulted in increased incidences of animal and crop diseases. Such scenarios present an extra risk of crop and animal production failure which in turn threatens household food security. This is more pronounced amongst smallholder farmers who usually have limited risk hedging strategies and rely on farm output for basic food supply. In this case, the role of agricultural extension is to link farmers to information and knowledge sources for adaptation to climate change and risk hedging. Moreover, extension services can aid farmer decision-making on viable livestock and crop diversification options to follow (Waha et al, 2018). Diversification is an important climate risk hedging strategy.

Agricultural extension plays a role in improving farmers' productivity and incomes, thereby reducing poverty and increasing food security. In the event that farmers are producing cash crops, increased productivity provides a pathway of earning income which can be utilised for food procurement (Conceição et al, 2016). Furthermore, increased productivity of food crops ensures increased availability of household food. The productivity of farmers is increased through application of appropriate knowledge in response to production challenges such as pests, diseases, and changes in weather patterns (FAO, 2017). Agricultural extension can play a role by ensuring that efforts towards increasing productivity are sustainable. Sustainable agricultural production ensures that current production activities do not compromise the production chances in the future. One way of achieving this is through agro-ecological practices (FAO, 2018). Agro-ecological practices are premised on empowering farmers as key 
agents of change while fostering co-creation of knowledge, integrating traditional, practical and local practices and skills for sustainable production (FAO, 2018).

An increase in farmers' incomes is achieved through market information and linking farmers to markets. Furthermore, training of farmers on product value addition can increase their incomes in comparison to marketing of raw agricultural products (Baipheti \& Jacobs, 2009). In addition, extension can link farmers to reliable and cheap sources of agricultural inputs and outputs, thereby culminating to low production cost and increased income. This contributes to the attainment of the sustainable development goal of ending hunger.

Despite current agricultural extension activities in South Africa, there is a considerable productivity and profitability gap amongst smallholder farming (Bjornlund \& Pittock, 2017). One major reason for this is an information, skill and resource gap that constrains the adoption of available technologies and management practices (Tire, 2006). Insufficient attention has been given to packaging of information and training materials into formats that help convey knowledge to farmers and extension workers, including input supplies and staff of financial service agencies and non-profit organisations (Bjornlund \& Pittock, 2017). Improving development communication is therefore critical in the South African extension system (Tire, 2006). The existing communication gap hinders the uptake of available and new technologies for improved production.

In addition to increasing productivity and income, another pathway for sustaining food security is through reduction of food waste. South Africa has one of the highest food waste rates in Africa and yet some households remain food insecure (Oelofse \& Nahman, 2013). Agricultural extension service can play a role in reduction of food waste through training farmers on hedging post-harvest losses and value addition. Appropriate processing of food crop after harvesting ensures prolonged household food availability and avoids losses (Hodges, Buzby \& Bennett, 2011). Access to post-harvesting methods and technology can be facilitated by agricultural extension services.

Agricultural extension is the primary delivery system for information to farmers in South Africa (Stevens \& Van Heerden, 2016). Improving agricultural production and sustainable food security in South Africa may not be achieved without relevant and reliable agricultural information. To fulfil its mission of effectively educating and facilitating learning amongst farmers, extension organisations in South Africa have to depend on research institutions to provide relevant and reliable information on improved technologies and practices (Davis \& Terblanché, 2016). In addition to this, extension personnel need to go for regular training so as to remain informed of current technological development which benefits farmers.

According to Munyua, Adams and Thomson (2002), the research-extension linkage is weak and is an institutional problem yet to be resolved. This further weakens agricultural and extension services in South Africa. Exploring and institutionalising linkages with other institutions is a strategy that extension organisations in South Africa can use to keep current with new information. Farmers, universities and colleges, private organisations, and nongovernmental organisations have not been fully acknowledged as potential information sources by extension organisations in South Africa (Munyua et al, 2002). Any existing relationships amongst extension and these institutions have been informal and indirect (Raidimi \& Kabiti, 2017). These institutions, however, are rich in knowledge and information. They also provide dynamism in information generation that can greatly enhance agricultural extension information needs and subsequently improve service provided to farmers, thereby resulting in 
sustainable food security (Baipheti \& Jacobs, 2009). The institutional linkages are vital, especially in the face of climate change where rapid information generation and application is needed for adaptation and sustainability purposes. Extension organisations, research institutions, farmer groups and organisations, as well as universities are all important stakeholders in the extension educational process.

\subsection{The role of agricultural education and training in achieving sustainable food security}

Education in one of the basic needs and is fundamental for the growth and development of human beings in both developed and developing countries (Rahman \& Uddin, 2009). Both education and training induce learning, a process that modifies knowledge and behaviour through teaching and experience. Training is communication intended for the purpose of developing skills, modifying behaviour, and increasing competence, targeted at a defined population and focusing exclusively on what needs to be known (Collett \& Gale, 2009). The purpose of education is gaining knowledge and developing intelligence in a basic sense, whilst targeting specific skills transfer (Subedi, 2004).

South Africa has one of the highest rates of public investment in education in the world with $5.3 \%$ of the GDP and $20 \%$ of the total state expenditure being spent on education (Burger, 2011). Formal education in agriculture is offered by 12 colleges of agriculture. In addition, six universities of technologies and 11 universities offer various tertiary agricultural education training programmes that are nationally accredited (DoA, 2008). Non-formal agricultural education is offered by a range of providers including public agricultural extension and training services, providers in the non-governmental organisations and private sectors, as well as universities, colleges and some agricultural high schools (DoA, 2008). Training agricultural professionals increases the skills of extension staff in the field and the lack of continuing education opportunities could constitute a drawback to agricultural extension agents' performance and thereby impacting on food security (Stevens \& Van Heerden, 2016). The training of extension personnel contributes directly to the development of human resources within extension organizations and sustainable food security.

The Department of Agriculture prioritises the development of appropriate agricultural skills amongst those previously excluded to ensure equitable participation in the agricultural sector to improve production and ensure sustainable food security (DoA, 2005). In this regard, a dedicated unit in the department for the promotion of appropriate agricultural skills was established. This unit came to be known as Education, Training and Extension Services. The purpose of the Directorate Education, Training and Extension, Training and Extension Services is to ensure that farmers and other stakeholders can access appropriate skills for the development of agriculture as an industry (DoA, 2005). This Directorate generally runs ad hoc in-service training programmes that do not prepare extension staff adequately to deal with complex agricultural problems. Training is a critical need and often inadequately provided in extension programmes in South Africa. In the year 2008 for example, only 427 out of 2155 (20\%) extension personnel in South Africa had a degree or higher qualification, while 1728 out of 2155 (80\%) had a diploma qualification (Williams et al, 2008). Overall, eight out of 10 extension personnel were insufficiently qualified to operate as agricultural advisors or subject matter experts. Very few extension officials in South Africa were exposed to formal skills programmes that address food security issues. Only 204 out of 2155 (9\%) extension officers had completed training in communication, $238(11 \%)$ had completed project management, 140 (6\%) had completed computer training, and $143(7 \%)$ had completed training related to people 
management and empowerment (Williams et al, 2008). Furthermore, only 25\% of extension staff were exposed to technical training programmes since joining the public service (Puhlisani, 2012; Williams et al, 2008).

Considering the identified shortfalls, strengthening training of extension agents for sustainable food security is therefore crucial. Improvements are needed in both pre-service (universities and colleges) and in-service training for extension agents. Training programmes need to emphasise new extension concepts and methodologies, as well as expand attention to marketing, communication, computer training, people management and empowerment, farm management, technical training, environmental issues, and the development of farmer and other client organisations (Spielman et al, 2008). This should be done whilst preserving people participation as a central concept of extension services (FAO, 2018). For sustainable and longterm development, investment in practical and well-rounded curricula for university programmes can provide a base for training the future generation of extension agents (Stevens \& Van Heerden, 2016). The Extension Recovery Plan (ERP) is one of the initiatives by the South African Department of Agriculture, Forestry and Fisheries which is identified as an activity in all provincial budget allocations for agriculture for skills upgrading for extension officers (DAFF, 2011). This is supported by a professional development programme focusing on developing high level skills for the benefit of the entire sector (DAFF, 2011). The impact of this initiative on sustainable food security is still to be seen (Liebenberg, 2015). While there are many complex factors that influence sustainable food security, education in agriculture plays an important role in preparing farmers, researchers, educators, extension staff, members of agri-businesses, and others role players to make productive contributions for sustainable food security (Allahyari, Chizari \& Mirdamadi, 2009; Chittoor \& Mishra, 2012). A critical issue is the changes and adaptations required in agricultural education for effective contributions to improved food security, sustainable agricultural production and rural development (Spielman et al, 2008). Poor training of agricultural extension staff in South Africa has been identified as part of the problem of the relative ineffectiveness of much of extension in the field (Davis \& Terblanché, 2016; Williams et al, 2008). There is a need for curricular and teaching programmes that are particularly relevant to the production needs and employment demands of the agricultural sector.

Therefore, there is a need to revise the pre-service education of extension workers towards an inter-disciplinary system approach to agricultural education (Spielman et al, 2008). Agricultural universities, colleges and schools in South Africa face major challenges. Meeting these challenges will require new educational strategies, innovative leadership and institutional reforms that take into account the current trends and factors that influence agricultural and rural development (Kabasa, Kirsten \& Minde, 2015). At present, the institutional relationships between agricultural teaching and research and extension services are inadequate (Raidimi \& Kabiti, 2017). This is a result of the deliberate separation of education, research and extension into different departments and agencies and a lack of functional mechanisms to link them together to solve common problems (Spielman et al, 2008). Agricultural research is usually conducted at government research stations and laboratories, the majority of which are not linked with universities. Research activities are often carried out as part of postgraduate programmes of higher agricultural education, but they are seldom directly related to national research priorities and policies. If linked, the research findings seldom find their way to practice or policy (Kabasa et al, 2015; Spielman et al, 2008). 
As with research, close working relationships between agricultural education institutions and extension systems are indispensable in order to ensure the relevance and contribution of agricultural education. The involvement of agricultural education institutions in extension and community outreach is often limited (Spielman et al, 2008). The institutional relationships between agricultural teaching and research and extension services and the involvement of agricultural education institutions in extension and community outreach in South Africa need to be strengthened for sustainable food security (Kabasa et al, 2015). The responsibility of agricultural extension should also fall on universities so that they provide training and technical support through subject-matter specialists (Spielman et al, 2008).

One way for universities and technical institutes to implement development outreach activities is by follow-up technical support to graduates working in agri-businesses or managing their own production enterprises (Davis \& Tereblanché, 2016). In addition, short courses of continuing education can be designed to update extension officers' knowledge and to qualify extension staff for career advancement (Spielman et al, 2008). Continuing education should, wherever possible, make use of farmers' associations (commodity associations), NGOs, as well as research and extension centres. Agricultural institutions, working with appropriate government agencies and NGOs, need to develop research and demonstration plots that directly address farmers' needs (Spielman et al, 2008). Commodity associations and farmer cooperatives could improve communication between agricultural education institutions and local producers (Mhembwe \& Dube, 2017).

Although agriculture has generally kept up with scientific progress in the past, the pace of change is much faster today, requiring the continuous updating of curricula (Stevens \& Van Heerden, 2016). The loss of natural resources and environmental degradation affects food security, hence, institutions of education in agriculture need to incorporate environmental and sustainable agricultural development issues into their curricula (Hamdy \& Aly, 2014). There is a need to place more emphasis on and include women as role models and leaders in agriculture in the curricula (Collett \& Gale, 2009). This will motivate more women to play an active role in agriculture at various levels. This is important considering the important role women play within farming families (FAO, 2017). Educational institutions need to place emphasis primarily on providing the types of courses that are important for preparing students as agricultural extension workers who can effectively communicate with diverse rural groups as well as support disadvantaged groups such as women and youth in a process of collaborative problem-solving (Collett \& Gale, 2009). In revising curricula for extension training, it is important to recognise that there has been a shift in thinking and in practice from expert-driven, technology-transfer extension approaches to collaborative learning approaches with participant groups (Collet \& Gale, 2009).

Curricula should therefore place less emphasis on theoretical models and more on the practical application of research. There is a need to provide an interdisciplinary perspective into which a wide range of different disciplinary components can be integrated and to provide experiential, field-based learning activities (Ghadei \& Rudd, 2017). Learning needs to emphasise inductive reasoning skills so that students can interpret problems and devise solutions (Sundtøl, 2004). Periodic curriculum review and revision, with a focus on local agricultural development problems and solutions are needed to keep the knowledge base relevant and to ensure that there is not a "cultural gap" between extension workers and the ultimate beneficiaries, namely the farmers (Kabasa et al, 2015). Changes to curriculum ensures that the new generation of agricultural extensionists are well equipped to deal with current challenges in a manner that 
ensures that it does not compromise the current and future producers (Stevens \& Van Heerden, 2016). The curricula must be composed of courses that help students think holistically, or in terms of integrated agricultural systems, so that they can understand the multi-dimensional nature of sustainable agricultural production. This requires an inter-disciplinary systems approach to agricultural education (Stevens \& Van Heerden, 2016).

Policy argues that agricultural productivity can be improved through Agricultural Education and Training (AET), research, and outreach (DoA, 2005). Furthermore, improved agricultural knowledge and competence are required, not only to improve primary agricultural production, but also for processing, storage and marketing of the produce and for successful implementation of agricultural policies in the country (Sundtøl, 2004). Agricultural education and training plays a major role towards agricultural development. The South African Agricultural Strategy for 2005 outlines the role of agricultural education towards development in terms of the provision and maintenance of sound education and training that support environmentally, socially and economically sustainable agricultural activities. Agricultural education and training is therefore vital for food self-sufficiency, poverty alleviation, and environmental protection amongst smallholder farmers (Collier \& Dercon, 2014). Education in all its forms has the potential to empower people by increasing their self-confidence, capacity to improve their livelihoods, and participation in wider processes of social and economic change (Stevens \& van Heerden, 2016). This in turn contributes to sustainable food security.

\section{CONCLUSION, RECOMMENDATIONS AND IMPLICATIONS}

This paper highlighted various means by which agricultural extension and training can help address food security at the household level. Given that in South Africa, most poor people live in rural areas and that agriculture is their main source of livelihood, focusing on factors that will enhance smallholder agriculture will bring about a lasting solution to the problems of rural poverty and food insecurity. Public agriculture extension service is the main support system available to smallholder farmers in South Africa. However, the extension personnel available are limited and not well prepared for the current production risks and threats faced by the smallholder farmers. As such, the South African agricultural extension service is challenged to improve food security and it is therefore vital that agriculture and agricultural extension and training remain an integral part of the government strategy to address food insecurity and poverty at household level. Developing knowledge and skills amongst farmers is one of the primary functions of agricultural extension and therefore extension programmes should be reexamined and adjusted so that they contribute to creating and maintaining food security at the household level.

Improving agricultural production for sustainable food security in South Africa may not be achieved without an effective agricultural extension service which is well linked to research information relevant to farmers' needs. The appropriateness and relevance of research findings and subsequent information used by extension agents to advise farmers is thus paramount for realising meaningful agricultural production and sustainable food security. Training institutions such as universities provide dynamism in information generation through their research and training activities that enhance agricultural extension information needs and subsequently important services provided to farmers, thereby resulting in sustainable food security. No country can develop without well aligned education systems which respond to the immediate needs of the people. To achieve food security for all, there is a need to develop a critical mass of new generation, dedicated, well-trained men and women to service the agricultural sector. 
In conclusion, this study revealed the central importance of agricultural extension services towards achieving sustainable food security in South Africa. The study revealed the importance of thorough and appropriate training of the extension personnel as contributors to the preparedness to deal with current agricultural planning, production and marketing challenges which affect household food security.

\section{REFERENCES}

ABDU-RAHEEM, K. \& WORTH, S.H., 2011. Household food security in South Africa: Evaluating extension's paradigms relative to the current food security and development goals. S. Afr. J. Agric. Ext., 39(2):91-103.

ALLAHYARI, M.S., CHIZARI, M. \& MIRDAMADI, S.M., 2009. Extension-education methods to facilitate learning in sustainable agriculture. J. Agri. Soc. Sci., 5(1-2):27-30.

BAIPHETI, M.N. \& JACOBS, P.T., 2009. The contribution of subsistence farming to food security in South Africa. Agrekon, 48(4):459-482.

BJORNLUND, H. \& PITTOCK, J., 2017. Exploring the productivity and profitability of smallscale communal irrigation systems in sub-Saharan Africa. Int. J. Water Resour. Dev., 33(5):658-689.

BURGER, D., 2011. South Africa information. Available from: https://www.gov.za/aboutsa/education

CAMPBELL, B.M., THORNTON, P., ZOUGMORÉ, R., VAN ASTEN, P. \& LIPPER, L., 2014. Sustainable intensification: What is its role in climate smart agriculture? Curr. Opin. Environ. Sustain., 8:39-43.

CHITTOOR, J. \& MISHRA, S., 2012. Agricultural education for sustainable rural development in developing countries: Challenges and policy options. J. Educ. Learn., 6(2):119-132.

COLLETT, K. \& GALE, C., 2009. Training for rural development: Agricultural and enterprise skills for women smallholders. City and Guilds Centre for Skills Development Report. London, England.

COLLIER, P. \& DERCON, S., 2014. African agriculture in 50 years: Smallholders in a rapidly changing world? World Dev., 63:92-101.

CONCEIÇÃO, P., LEVINE, S., LIPTON, M. \& WARREN-RODRÍGUEZ, A., 2016. Toward a food secure future: Ensuring food security for sustainable human development in subSaharan Africa. Food Policy, 60:1-9.

DAVIS, K.E. \& TERBLANCHÉ, S., 2016. Challenges facing the agricultural extension landscape in South Africa, Quo Vadis? S. Afr. J. Agric. Ext., 44(2):231-247.

DEPARTMENT OF AGRICULTURE (DoA), 2005. Agricultural Education and Training (AET) strategy for agriculture and rural development in South Africa. Available from: https://www.nda.agric.za/doaDev/sideMenu/educationAndTraining/AET_\%20executiv e_summary.pdf

DEPARTMENT OF AGRICULTURE (DoA), 2008. Agricultural Education and Training Access Barriers Report. Available from: 
https://www.nda.agric.za/doaDev/sideMenu/educationAndTraining/AET_ACCESS_B ARRIERS_TO_AET.pdf

DEPARTMENT OF AGRICULTURE, FORESTRY AND FISHERIES (DAFF), 2011. National framework for extension recovery plan. Available from: https://www.nda.agric.za/doaDev/sideMenu/educationAndTraining/framework_recover y\%20plan_web.pdf

DEPARTMENT OF AGRICULTURE, FORESTRY AND FISHERIES (DAFF), 2012. Breakdown of extension officers in South Africa per provinces. Pretoria. South Africa.

FOOD AND AGRICULTURE ORGANIZATION OF THE UNITED NATIONS (FAO), 2017. The state of food security and nutrition in the world 2017: Building resilience for peace and food security. Available from: http://www.fao.org/3/a-I7695e.pdf

FOOD AND AGRICULTURE ORGANIZATION OF THE UNITED NATIONS (FAO), 2018. The 10 elements of agroecology: Guiding the transition to sustainable food and agricultural systems. Available from: http://www.fao.org/3/I9037EN/i9037en.pdf

GHADEI, K. \& RUDD, R., 2017. Making sense and consensus for agricultural training and education to cope with climate change. J. Glob. Commun., 10(1):47-53.

HAMDY, A. \& ALY, A., 2014. Land degradation, agriculture productivity and food security. Paper presented to The Fifth International Scientific Agricultural Symposium. Jahorina, Bosnia and Herzegovina.

HODGES, R., BUZBY, J. \& BENNETT, B., 2011. Postharvest losses and waste in developed and less developed countries: Opportunities to improve resource use. J. Agric. Sci., 149(1):37-45.

INTERNATIONAL LABOUR ORGANISATION (ILO), 2007. Key indicators of the labour market. Rome, Italy.

KABASA, S., KIRSTEN, J. \& MINDE, I.J., 2015. Implications of changing agri-food system structure for agricultural education and training in sub-Saharan Africa. JADEE., 5(2):190-199.

LIEBENBERG, F., 2015. Agricultural advisory services in South Africa. Available from: http://ageconsearch.umn.edu/bitstream/241722/2/agric_advisory_services.zp 64017.pdf

MHEMBWE, S. \& DUBE, E., 2017. The role of cooperatives in sustaining the livelihoods of rural communities: The case of rural cooperatives in Shurugwi District, Zimbabwe. Jamba, 9(1):1-9.

MSUYA, C.P., ANNOR-FREMPONG, F.K., MAGHENI, M.N., AGUNGA, R., IGODAN, C., LADELE, A., HUHELA, K., TSELAESELE, N.M., MSATILOMO, H., CHOMO, C. \& ZWANE, E., 2017. The role of agricultural extension in Africa's development: The importance of extension workers and the need for change. Int. J. Agric. Ext., 5(1):51-58.

MUNYUA, C., ADAMS, P. \& THOMSON, J., 2002. Designing effective linkages for sustainable agricultural extension information systems among developing countries in sub-Saharan Africa. Paper presented to The 18th AIAEE Annual Conference. Durban, South Africa.

OELOFSE, S.H. \& NAHMAN, A., 2013. Estimating the magnitude of food waste generated in South Africa. Waste Manag. Res., 31(1):80-86. 
ORGANISATION FOR ECONOMIC CO-OPERATION DEVELOPMENT (OECD), 2016. Agriculture in sub-Saharan Africa: Prospects and challenges for the next decade. In OECD-FAO Agricultural Outlook 2016-2025 (pp.59-95). Paris: OECD Publishing.

PUHLISANI, 2012. Towards a new policy on extension for agriculture, forestry and fisheries. Cape Town, South Africa.

RAHMAN, U. \& UDDIN, S., 2009. Statistical analysis of different socio economic factors affecting education of NWFP (Pakistan). J. Appl. Quant. Methods, 4(1):88-94.

RAIDIMI, E. \& KABITI, H., 2017. Agricultural extension, research, and development for increased food security: The need for public-private sector partnerships in South Africa. S. Afr. J. Agric. Ext., 45(1):49-63.

SPIELMAN, D.J., EKBOIR, J., DAVIS, K. \& OCHIENG, C.M., 2008. An innovation systems perspective on strengthening agricultural education and training in sub-Saharan Africa. Agric. Sys., 98(1):1-9.

STAAZ, I. \& DEMBELE, N., 2008. Agriculture for development in sub-Saharan Africa. Available from: https://pdfs.semanticscholar.org/713e/7cc678662b565ca20b7bb80a29a28397ba72.pdf

STEVENS, J.B. \& VAN HEERDEN, P.S., 2016. Knowledge brokering and dissemination of irrigation management guidelines for training of extension advisors. Report No. KV, 356, 16.

SUBEDI, B., 2004. Emerging trends of research on transfer of learning. Int. Educ. J., 5(4):591599.

SUNDTØL, F., 2004. Poverty reduction strategies and relevant participatory learning processes in agricultural higher education. Available from: www.umb.no/statisk/noragric/publications/reports/2004_nor_rep_21a.pdf

TIRE, M., 2006. An evaluation of the information dissemination mechanisms for small scale subsistence farmers. PhD Thesis, University of Stellenbosch.

VAN DER BERG, S., 2006. Public spending and the poor since the transition to democracy. In Poverty and policy in post apartheid South Africa (pp.201-231). Cape Town: Human Sciences Research Council Press.

WAHA, K., VAN WIJK, M.T., FRITZ, S., SEE, L., THORNTON, P.K., WICHERN, J. \& HERRERO, M., 2018. Agricultural diversification as an important strategy for achieving food security in Africa. Glob. Change Biol., 24(8):3390-3400.

WILLIAMS, B., MAYSON, D., DE SATGÈ, R., EPSTEIN, S. \& SEMWAYO, T., 2008. Extension and smallholder agriculture: Key issues from a review of the literature. Available from: www.phuhlisani.com/oid\%5Cdownloads\%5CPhuhlisani\%20extension\%20reviewD1.p $\underline{\mathrm{df}}$

ZWANE, M. \& MONTMASSON-CLAIR, G., 2016. Climate change adaptation and agriculture in South Africa: A policy assessment. Available from: https://www.tips.org.za/research-archive/sustainable-growth/green-economy2/item/3140-climate-change-adaptation-and-agriculture-in-south-africa-a-policyassessment. 
